\title{
Effect of Evolocumab on Lipoprotein Particles
}

Peter P. Toth, MD, PhD, ${ }^{a, b}$ Naveed Sattar, MD, ${ }^{c}$ Dirk J. Blom, MD, PhD, ${ }^{d}$ Seth S. Martin, MD, MHS, ${ }^{b}$ Steven R. Jones, MD, ${ }^{b}$ Maria Laura Monsalvo, MD, ${ }^{e}$ Mary Elliott, MSci, ${ }^{\dagger}$ Mike Davis, MA, Ransi Somaratne, $\mathrm{MD},{ }^{e}$ David Preiss, $\mathrm{PhD}^{\mathrm{g}}$

${ }^{a}$ CGH Medical Center, Sterling, IL, USA; ${ }^{b}$ Ciccarone Center for the Prevention of Heart Disease, Johns Hopkins University School of Medicine, Baltimore, MD, USA; 'University of Glasgow, Glasgow, UK; 'Division of Lipidology, Department of Medicine, University of Cape Town, Cape

Town, South Africa; ${ }^{\mathrm{e} A m g e n}$ Inc., Thousand Oaks, CA, USA; 'Amgen Ltd., Cambridge, UK;

${ }^{9}$ MRC Population Health Research Unit, Clinical Trial Service Unit and Epidemiological Studies Unit, Nuffield Department of Population Health, University of Oxford, Oxford, UK

\section{Corresponding Author:}

Peter P. Toth, MD, PhD

Director of Preventative Cardiology

CGH Medical Center

Sterling, Illinois

Email: Peter.Toth@cghmc.com

Tel: (815) 632-5093

FAX: (815) 626-5947

\section{Running head: Evolocumab and lipoprotein particles}




\section{ABSTRACT}

The level of low-density lipoprotein cholesterol (LDL-C) reflects the cholesterol carried mainly by low-density lipoprotein particles (LDL-P). LDL-C, however, does not always correlate with LDL-P because of the variable amounts of cholesterol per particle. Consideration of LDL-P concentrations in addition to LDL-C may help guide therapeutic decisions in a select number of patients. Evolocumab is a fully human monoclonal antibody directed against proprotein convertase subtilisin-kexin type 9 that lowers both LDL-C and cardiovascular events. To evaluate the effect of evolocumab on serum levels and size of lipoprotein particles, we conducted a post-hoc subanalysis of 619 patients from the DESCARTES trial, a 52-week, randomized, double-blind, placebo-controlled, global study of patients with hyperlipidemia. At baseline, mean LDL-P concentration was $1,077 \mathrm{nmol} / \mathrm{L}$ for the placebo group and 1,100 nmol/L for the evolocumab group. In patients receiving evolocumab, week 52 total LDL-P concentration decreased to $610 \mathrm{nmol} / \mathrm{L}$, a treatment difference of $50 \%$ versus placebo. Evolocumab also reduced concentrations of medium VLDL-P, small VLDL-P, and IDL-P: median (Q1, Q3) changes were $-15.2 \%(-48,48),-29 \%(-54,18)$, and $-36 \%(-70,22)$, respectively. Mean $(95 \%$ CI) percent changes in total LDL particle size in the evolocumab group was $-1.7(-2.0,-1.4)$; percent changes in HDL and VLDL particle sizes were $1.1(0.7,1.5)$ and $8.7(7.0,10.5)$, respectively. Changes in total LDL, HDL, and VLDL particle sizes (versus placebo) were all significant $(P<.001)$. In conclusion, evolocumab significantly lowers atherogenic lipoprotein particles including low-density and remnant lipoproteins.

Keywords (2-4): cholesterol, evolocumab, lipoprotein, remnant lipoproteins 


\section{INTRODUCTION}

Proprotein convertase subtilisin/kexin type 9 (PCSK9) is a serine protease that inhibits LDL receptor (LDL-R) recycling. Evolocumab is a fully human monoclonal antibody that targets PCSK9 and prevents it from binding to the LDL-R. This increases LDL-R density on the surface of hepatocytes and, consequently, clearance rates of LDL-C from the blood. Evolocumab markedly lowers LDL-C in multiple clinical settings ${ }^{1-6}$ and reduces the risk of cardiovascular events. ${ }^{7}$ Although the effect of evolocumab on LDL-C levels is well characterized, little is known about its effects on lipoprotein particles or particle subfractions. The objective of this post hoc analysis was to evaluate the effect of evolocumab on lipoprotein particle concentrations as assessed by NMR spectroscopy in patients from the phase 3, 52-week DESCARTES (Durable Effect of PCSK9 Antibody Compared with Placebo Study, NCT01516879) trial.

\section{METHODS}

The DESCARTES trial was a 52-week, randomized, double-blind, placebo-controlled, multicenter, global study of patients with hyperlipidemia. Full details have been published previously. ${ }^{1}$ DESCARTES was an LDL-C lowering trial and particle analyses were conducted post hoc. Briefly, patients were eligible to participate if they were aged 18 to 75 years with an LDL-C $\geq 1.9 \mathrm{mmol} / \mathrm{L}(75 \mathrm{mg} / \mathrm{dL})$ and a fasting triglyceride level $\leq 4.5 \mathrm{mmol} / \mathrm{L}(400 \mathrm{mg} / \mathrm{dL})$ following optimization of lipid lowering therapy in the run-in period. Based on cardiovascular risk, statin use, and baseline LDL-C, patients were assigned to diet alone, diet with $10 \mathrm{mg}$ of atorvastatin daily, diet with $80 \mathrm{mg}$ of atorvastatin daily, or diet with $80 \mathrm{mg}$ of atorvastatin plus 10 $\mathrm{mg}$ of ezetimibe daily. The intensity of lipid-lowering therapy was increased stepwise until patients were at LDL-C target (NCEP ATP III, based on CV risk) or were receiving maximal therapy. After the run-in period, eligible patients were randomized 1:2 to receive placebo or evolocumab $420 \mathrm{mg}$ monthly. For this subanalysis, patients were randomly selected with a greater weight given to patients with diabetes and patients who received placebo (to produce a 
ratio nearer to $1: 1$ between treatment groups). Baseline was defined as study day 1 following lipid stabilization. Lipids and lipoprotein particle concentrations were analyzed at day 1 following lipid stabilization (baseline) and week 52. An independent ethics committee/institutional review board approved the protocol prior to study initiation at all sites. All patients provided written informed consent before enrollment.

Serum concentrations levels of lipoprotein particles (LDL, high-density lipoprotein [HDL], and VLDL/chylomicrons) and remnant lipoproteins (including small VLDL and IDL), as well as particle sizes, were measured using nuclear magnetic resonance (NMR) spectroscopy. ${ }^{8}$ This method uses the amplitude of terminal lipid methyl group NMR signals to determine the particle concentration of lipoprotein subclasses. ${ }^{8}$ Signal amplitudes were deconvoluted using the LipoProfile-3 algorithm, a model that is able to differentiate $>30$ discrete subpopulations of lipoprotein particles. ${ }^{8}$ Briefly, diameter ranges of lipoprotein subclasses are: VLDL, 27 - >60 nm; IDL, $23-27 \mathrm{~nm}$; LDL, $18-23 \mathrm{~nm}$; and HDL, $7.3-13 \mathrm{~nm} \cdot{ }^{8,9}$ LDL-C was calculated using the Friedewald equation; VLDL-C was determined by ultracentrifugation. Baseline lipid levels (LDLC, HDL-C, triglycerides, VLDL-C, and total cholesterol) were calculated by taking the mean of screening and day 1 values if available. IDL-C levels were not measured in the DESCARTES study.

LDL-P, and HDL-P were analyzed using mean absolute values at week 52 and mean percent change from baseline to week 52. The treatment differences for evolocumab versus placebo for these analytes were tested using two-sample t-tests. Large LDL-P, small LDL-P, medium VLDL-P, small VLDL-P, VLDL-P/chylomicron, and IDL-P were analyzed using median absolute values at week 52 and median percent change from baseline to week 52 . The treatment differences for evolocumab versus placebo for these analytes were tested using Wilcoxon rank sum tests. All p-values are nominal, and no adjustment for multiplicity was performed. Particle sizes were determined using the total weighted average size for all subclasses of VLDL, LDL, and HDL particles. Differences were tested using two-sample t-tests. 
No imputation was performed for missing data. Statistical analyses were conducted in SAS version 9.4 (SAS Institute, Cary, NC).

We evaluated the effect of evolocumab on LDL-P under conditions of baseline concordance and discordance (LDL-C > LDL-P or LDL-C < LDL-P). Discordance was defined as LDL-C and LDL-P values differing by > 14 percentile units resulting in approximately equal numbers of patients categorized as either concordant or discordant. ${ }^{9}$

\section{RESULTS}

Demographic data, baseline characteristics, lipid levels, and lipoprotein and remnant particle concentrations were available in 619 patients (Table 1). In total, 55\% and 49\% were women; $83 \%$ and $78 \%$ were white; and $14 \%$ and $18 \%$ had coronary artery disease, for placebo and evolocumab cohorts, respectively. This population is enriched for patients with diabetes, who made up $15 \%$ and $23 \%$ of the placebo and evolocumab groups.

At baseline, lipid measures and lipid particle values were comparable for placebo and evolocumab groups (Table 1). Briefly, for the placebo and evolocumab groups, the mean \pm SD LDL-C was $99.8 \mathrm{mg} / \mathrm{dL} \pm 21.6$ and $100.7 \mathrm{mg} / \mathrm{dL} \pm 23.8$, respectively; the mean \pm SD LDL-P was $1077.1 \mathrm{nmol} / \mathrm{L} \pm 274.5$ and $1100.2 \mathrm{nmol} / \mathrm{L} \pm 286.0$, respectively. The remainder of the lipoprotein values can be found in Table 1.

Beneficial changes were seen in LDL-C and other lipids in patients treated for 52 weeks with evolocumab (Table 2). At week 52, average LDL-C was markedly reduced, HDL-C increased, and triglycerides reduced in the evolocumab group compared with placebo (Table 2). Mean \pm SE percent changes in LDL-C from baseline to week 52 for the placebo and evolocumab groups were $7 \% \pm 1.8$ and $-53 \% \pm 1.7$, respectively. Evolocumab reduced apolipoprotein B (apoB), reduced the apoB/A1 ratio, and increased apoAI. (Table 2).

Changes in lipoprotein particle concentrations are reported in Table 3. At week 52, very low levels of total LDL-P were achieved in the majority of patients taking evolocumab. 
Compared with placebo, evolocumab induced reductions in total LDL-P as well as small and large LDL-P. Evolocumab increased total HDL-P, as well as its small, medium, and large HDLP species. 52 weeks evolocumab therapy was associated with reductions in the median total VLDL-P/chylomicron, medium VLDL-P, small VLDL-P, and IDL-P. The concentration of large VLDLwas increased by evolocumab..

Lipoprotein particle changes were also analyzed according to glycemic status at baseline, with patients differentiated by whether they had type 2 diabetes, impaired fasting glucose or met the defined diagnostic criteria for metabolic syndrome (modified from AHA/NHLBI). ${ }^{10}$ There was remarkable consistency in the effect of evolocumab on serum levels of LDL-P, HDL-P, VLDL-P/chylomicrons, and IDL-P, with no substantive differences between these patient groups (Supplemental Table 1).

Distribution of LDL-C and LDL-P values at baseline are shown in Figure 1. Compared with placebo, evolocumab induced robust reductions in both LDL-C and total LDL-P, regardless of their concordance status at baseline (Table 4). These results were comparable to those obtained using an alternative method of estimating LDL-C (Supplemental Table 2).

The net size of LDL-P decreased significantly for the group as a whole, as well as for patients with impaired fasting glucose or metabolic syndrome; a decrease (not significant) was also observed for those with type 2 diabetes (Table 5). Evolocumab increased HDL particle and VLDL particle sizes for all groups.

\section{DISCUSSION}

This post hoc analysis of patients enrolled in the DESCARTES trial demonstrates that evolocumab induces marked reductions in LDL-C and LDL-P after 52 weeks of evolocumab exposure. Prior to the DESCARTES analysis, the effect of evolocumab on lipoprotein particles had only been assessed at two weeks after initiating evolocumab. Here, favorable changes of lipoprotein particle concentration and size are observed shortly after initiating evolocumab and 
are maintained with long-term treatment. Furthermore, these patterns are consistent across this study population which was enriched for patients with diabetes. Both LDL-C and LDL-P were reduced from the Framingham $20^{\text {th }}$ percentile to $<2^{\text {nd }}$ percentile, which represents a marked shift in atherogenic lipoprotein burden. Put in context, in a comprehensive analysis of 8 studies, the mean percent reduction of LDL-P is 31 and the mean attained LDL-P percentile is 51 with statin monotherapy. ${ }^{11}$ As demonstrated herein, the adjuvant use of evolocumab in patients treated with a statin provides more substantial reductions in these two measures. Evolocumab substantially reduced triglyceride enriched lipoprotein particles including a sum of chylomicron and large VLDL particles, small VLDL-P, and IDL-P. Both HDL-C and HDL-P increased. This therapeutic impact on lipoprotein fractions of evolocumab was consistent across all patient groups studied.

Evolocumab reduced both large and small LDL-P. The percentage reduction in large LDL-P was approximately twice that of small LDL-P, which likely accounts for the reduction in average LDL particle size. This may be a manifestation of less efficient clearance of small, dense LDL particles by the LDL-R compared to larger LDL particles. ${ }^{12}$ Medium and large HDL-P increased and this was associated with a modest rise in average HDL particle size. Although small VLDL-P decreased, there was a rise in large VLDL-P. The precise etiology for this increase is not clear.

Overall, the changes reported here are consistent with those reported with alirocumab (150 mg every two weeks), although that study was shorter in duration (12 weeks), excluded patients with diabetes, and involved a smaller sample size of 31 patients. $^{13}$

The effect of evolocumab on lipoprotein particle number and size were consistent regardless of concordance at baseline and regardless of whether the patient had diabetes, impaired fasting glucose, or metabolic syndrome. If LDL-C and LDL-P values are discordant, LDL-P levels may be important to consider when assessing cardiovascular risk. This could be important in patients with diabetes, who may be more likely to have discordance. ${ }^{9}$ Thus, there 
may be clinical importance in quantifying the effects of any lipid-lowering therapy on LDL-P as well as LDL-C.

The monoclonal antibodies directed against PCSK9 can reduce LDL-C to very low levels, especially when used in combination with high-dose, high-potency statins. Though there have been reservations about the safety of very low LDL-C levels, no safety signals have been discerned in either the Improved Reduction of Outcomes: Vytorin Efficacy International Trial (IMPROVE-IT), ${ }^{14,15}$ in which the mean LDL-C level at 1 year was $53.2 \mathrm{mg}$ per deciliter in the simvastatin plus ezetimibe group, or the Further Cardiovascular Outcomes Research with PCSK9 Inhibition in Subjects with Elevated Risk (FOURIER) trial, in which $42 \%$ of patients in the evolocumab group achieved an LDL-C level of $25 \mathrm{mg}$ per deciliter or lower at 48 weeks. ${ }^{7}$ As shown here, even when LDL-C approaches very low levels, there are still a substantial number of LDL particles available in serum irrespective of concordance.

Evolocumab provides robust reductions in LDL-C and LDL-P secondary to its capacity to significantly upregulate expression of the LDL receptor. However, PCSK9 also regulates expression of the VLDL receptor, LDL receptor-related protein, and apolipoprotein $\mathrm{E}$ receptor 2 (apoER2). ${ }^{16,17}$ In this study evolocumab therapy clearly potentiated reductions of triglycerideenriched lipoproteins, including VLDL-P and IDL-P. It is possible that the aforementioned receptors may play roles in facilitating the clearance of these lipoproteins thereby leading to their augmented clearance from the systemic circulation. The LDLR is also involved in remnant clearance via apoE binding and upregulating it may thus also improve remnant clearance. ${ }^{18}$

Though the mechanism is not yet well understood, evolocumab treatment is associated with modest elevations in both HDL-C and HDL-P. To date, there is no evidence to suggest that PCSK9 modulates HDL-P production or clearance; thus, the effect of evolocumab on HDL levels may be largely indirect. With lower availability of apoprotein B-containing particles in serum (LDL, VLDL, and IDL), it is possible that there is less enrichment of the HDL fraction with 
triglyceride by cholesterol ester transfer protein. This could help to preserve or increase levels of HDL in blood via less catabolism of HDL by hepatic lipase.

Though the small intestine does express PCSK9, ${ }^{19}$ it is not yet clear whether PCSK9 plays any role in regulating chylomicron production or secretion. Current NMR methodology and deconvolution programs cannot independently estimate serum levels of chylomicrons. Among patients treated with evolocumab in DESCARTES, the combined fraction of VLDL/chylomicrons (lipoproteins secreted from the liver and jejunum) was decreased. Considering that all patients were fasting and patients with hypertriglyceridemia $(<4.5 \mathrm{mmol} / \mathrm{L})$ were excluded from DESCARTES, it is unlikely that this subset of patients would have significant amounts of circulating chylomicrons. Whether the VLDL/chylomicron reduction was secondary to increased clearance, reduced production, or both, and from which fractions remains to be determined.

In conclusion, evolocumab significantly lowered atherogenic lipoprotein particles including low-density lipoprotein and remnant lipoproteins. 


\section{DISCLOSURES}

PPT reports receiving consulting fees from Amarin, Amgen, AstraZeneca, Gemphire, Kowa, Merck, and Sanofi/Regeneron and serving on speakers bureaus for Amarin, Amgen, Kowa, Merck, and Regeneron-Sanofi. NS reports receiving consulting fees from Amgen, Sanofi, and Merck. DJB reports that his institution has received research grants from Sanofi-Aventis, Regeneron, Novartis, Eli Lilly \& Company, Amgen, and Aegerion; and reports receiving consulting fees from Aegerion and Gemphire for serving on steering committees; receiving fees for serving on advisory boards for Sanofi-Aventis, Aegerion, Amgen, AstraZeneca, and MSD; receiving honoraria for lectures from Sanofi-Aventis, Regeneron, Aegerion, Amgen, AstraZeneca, MSD, Pfizer, Servier, and Unilever; receiving travel assistance from Amgen and Aegerion; and receiving non-financial support (editorial assistance and statistical analyzes) from Sanofi-Aventis and Regeneron. SSM reports research grants to his institution from the Aetna Foundation, American Heart Association, Maryland Innovation Initiative, Nokia/Withings, Apple, and Google; and he reports receiving consulting fees from Abbott Nutrition, Pressed Juicery, Quest Diagnostics, Amgen, Sanofi/Regeneron, and the Pew Research Center. SSM and SRJ reports serving as co-inventors on a pending patent for a novel method of LDL-C calculation filed by Johns Hopkins University. SRJ has no other conflicts of interest to report. MLM, ME, RS, and MD are all Amgen employees and report that they own Amgen stocks/stock options. DP reports having received consulting fees from Sanofi on three occasions, all in 2013/2014, during previous employment.

\section{FUNDING}

This study was funded by Amgen Inc.

\section{ROLE OF THE FUNDER/SPONSOR}


Amgen had a role in the design and conduct of the study; collection, management, analysis, and interpretation of the data; and preparation, review, and approval of the manuscript.

\section{ACKNOWLEDGEMENTS}

The authors acknowledge Lynn Griffin, PhD, of Amgen Inc. and Katherine Hsu, PharmD, on behalf of Amgen Inc., for providing editorial support. 
1. Blom DJ, Hala T, Bolognese M, Lillestol MJ, Toth PD, Burgess L, Ceska R, Roth E, Koren MJ, Ballantyne CM, Monsalvo ML, Tsirtsonis K, Kim JB, Scott R, Wasserman SM, Stein EA, for the DESCARTES Investigators. A 52-week placebo-controlled trial of evolocumab in hyperlipidemia. N Engl J Med 2014;370:1809-1819.

2. Koren MJ, Lundqvist P, Bolognese M, Neutel JM, Monsalvo ML, Yang J, Kim JB, Scott R, Wasserman SM, Bays H, MENDEL-2 Investigators. Anti-PCSK9 monotherapy for hypercholesterolemia: the MENDEL-2 randomized, controlled phase III clinical trial of evolocumab. J Am Coll Cardiol 2014;63:2531-2540. 3. Raal FJ, Honarpour N, Blom DJ, Hovingh GK, Xu F, Scott R, Wasserman SM, Stein EA, for the TESLA Investigators. Inhibition of PCSK9 with evolocumab in homozygous familial hypercholesterolaemia (TESLA Part B): a randomised, double-blind, placebo-controlled trial. Lancet 2015;385:341-350.

4. Raal FJ, Santos RD, Blom DJ, Marais AD, Charng MJ, Cromwell WC, Lachmann RH, Gaudet D, Tan JL, Chasan-Taber S, Tribble DL, Flaim JD, Crooke ST. Mipomersen, an apolipoprotein B synthesis inhibitor, for lowering of LDL cholesterol concentrations in patients with homozygous familial hypercholesterolaemia: a randomised, double-blind, placebo-controlled trial. Lancet 2010;375:998-1006. 5. Robinson JG, Nedergaard BS, Rogers WJ, Fialkow J, Neutel JM, Ramstad D, Somaratne R, Legg JC, Nelson P, Scott R, Wasserman SM, Weiss R, LAPLACE-2 Investigators. Effect of evolocumab or ezetimibe added to moderate- or high-intensity statin therapy on LDL-C lowering in patients with hypercholesterolemia: the LAPLACE-2 randomized clinical trial. JAMA 2014;311:1870-1882.

6. Stroes E, Colquhoun D, Sullivan D, Civeira F, Rosenson RS, Watts GF, Bruckert E, Cho L, Dent R, Knusel B, Xue A, Scott R, Wasserman SM, Rocco M, GAUSS-2 Investigators. Anti-PCSK9 antibody effectively lowers cholesterol in patients with statin intolerance: the GAUSS-2 randomized, placebo-controlled phase 3 clinical trial of evolocumab. J Am Coll Cardiol 2014;63:2541-2548. 
7. Sabatine MS, Giugliano RP, Keech AC, Honarpour N, Wiviott SD, Murphy SA, Kuder JF, Wang H, Liu T, Wasserman SM, Sever PS, Pedersen TR. Evolocumab and Clinical Outcomes in Patients with Cardiovascular Disease. N Engl J Med 2017;376:1713-1722.

8. Jeyarajah EJ, Cromwell WC, Otvos JD. Lipoprotein particle analysis by nuclear magnetic resonance spectroscopy. Clin Lab Med 2006;26:847-870.

9. Otvos JD, Mora S, Shalaurova I, Greenland P, Mackey RH, Goff DC, Jr. Clinical implications of discordance between low-density lipoprotein cholesterol and particle number. J Clin Lipidol 2011;5:105113.

10. Executive Summary of The Third Report of The National Cholesterol Education Program (NCEP) Expert Panel on Detection, Evaluation, And Treatment of High Blood Cholesterol In Adults (Adult Treatment Panel III). JAMA 2001;285:2486-2497.

11. Sniderman AD. Differential response of cholesterol and particle measures of atherogenic lipoproteins to LDL-lowering therapy: implications for clinical practice. J Clin Lipidol 2008;2:36-42. 12. Galeano NF, Milne R, Marcel YL, Walsh MT, Levy E, Ngu'yen TD, Gleeson A, Arad Y, Witte L, AlHaideri M, Rumsey SC, Deckelbaum RJ, et al. Apoprotein B structure and receptor recognition of triglyceride-rich low density lipoprotein (LDL) is modified in small LDL but not in triglyceride-rich LDL of normal size. J Biol Chem 1994;269:511-519.

13. Koren MJ, Kereiakes D, Pourfarzib R, Winegar D, Banerjee P, Hamon S, Hanotin C, McKenney JM. Effect of PCSK9 Inhibition by Alirocumab on Lipoprotein Particle Concentrations Determined by Nuclear Magnetic Resonance Spectroscopy. J Am Heart Assoc 2015;4.

14. Cannon CP, Blazing MA, Giugliano RP, McCagg A, White JA, Theroux P, Darius H, Lewis BS, Ophuis TO, Jukema JW, De Ferrari GM, Ruzyllo W, De Lucca P, Im K, Bohula EA, Reist C, Wiviott SD, Tershakovec AM, Musliner TA, Braunwald E, Califf RM. Ezetimibe Added to Statin Therapy after Acute Coronary Syndromes. N Engl J Med 2015;372:2387-2397. 
15. Giugliano RP, Wiviott SD, Blazing MA, De Ferrari GM, Park JG, Murphy SA, White JA, Tershakovec AM, Cannon CP, Braunwald E. Long-term Safety and Efficacy of Achieving Very Low Levels of Low-Density Lipoprotein Cholesterol : A Prespecified Analysis of the IMPROVE-IT Trial. JAMA Cardiol 2017;2:547-555. 16. Poirier S, Mayer G, Benjannet S, Bergeron E, Marcinkiewicz J, Nassoury N, Mayer H, Nimpf J, Prat A, Seidah NG. The proprotein convertase PCSK9 induces the degradation of low density lipoprotein receptor (LDLR) and its closest family members VLDLR and ApoER2. J Biol Chem 2008;283:2363-2372. 17. Canuel M, Sun X, Asselin MC, Paramithiotis E, Prat A, Seidah NG. Proprotein convertase subtilisin/kexin type 9 (PCSK9) can mediate degradation of the low density lipoprotein receptor-related protein 1 (LRP-1). PLoS One 2013;8:e64145.

18. Mahley RW, Hui DY, Innerarity TL, Beisiegel U. Chylomicron remnant metabolism. Role of hepatic lipoprotein receptors in mediating uptake. Arteriosclerosis 1989;9:I14-18.

29. Ferri N. Proprotein convertase subtilisin/kexin type 9: from the discovery to the development of new therapies for cardiovascular diseases. Scientifica (Cairo) 2012;2012:927352. 


\section{TABLES}

Table 1. Baseline demographics, clinical characteristics, lipids, and lipoprotein particles

\begin{tabular}{|c|c|c|}
\hline Variable & $\begin{array}{l}\text { Placebo } \\
(n=283)\end{array}$ & $\begin{array}{c}\text { Evolocumab } \\
420 \text { mg QM } \\
(n=336)\end{array}$ \\
\hline Women & $157(55.5 \%)$ & $166(49.4 \%)$ \\
\hline White & $234(82.7 \%)$ & $263(78.3 \%)$ \\
\hline Age (years), mean \pm SD & $57.1 \pm 10.0$ & $56.4 \pm 10.6$ \\
\hline Coronary artery disease & $41(14.5 \%)$ & $59(17.6 \%)$ \\
\hline Cerebrovascular or peripheral artery disease & $11(3.9 \%)$ & $17(5.1 \%)$ \\
\hline Type 2 diabetes & $43(15.2 \%)$ & $77(22.9 \%)$ \\
\hline Body mass index $\left(\mathrm{kg} / \mathrm{m}^{2}\right)$, mean $\pm \mathrm{SD}$ & $30.5 \pm 5.7$ & $30.2 \pm 6.2$ \\
\hline Waist circumference $(\mathrm{cm})$, mean \pm SD & $100.9 \pm 14.3$ & $99.9 \pm 13.5$ \\
\hline $\mathrm{LDL}-\mathrm{C}(\mathrm{mg} / \mathrm{dL})$, mean $\pm \mathrm{SD}$ & $99.8 \pm 21.6$ & $100.7 \pm 23.8$ \\
\hline VLDL-C (mg/dL), median (Q1, Q3) & $18.5(13.0,28.5)$ & $18.5(13.0,25.0)$ \\
\hline $\mathrm{HDL}-\mathrm{C}(\mathrm{mg} / \mathrm{dL})$, mean $\pm \mathrm{SD}$ & $53.4 \pm 16.4$ & $51.7 \pm 15.0$ \\
\hline Triglycerides (mg/dL), median (Q1, Q3) & $112.0(86.0,162.0)$ & $110.8(79.5,149.5)$ \\
\hline Total cholesterol $(\mathrm{mg} / \mathrm{dL})$, mean $\pm \mathrm{SD}$ & $179.1 \pm 27.6$ & $176.9 \pm 28.3$ \\
\hline LDL-P total $(\mathrm{nmol} / \mathrm{L})$, mean $\pm \mathrm{SD}$ & $1077.1 \pm 274.5$ & $1100.2 \pm 286.0$ \\
\hline Large LDL-P (nmol/L), median (Q1, Q3) & $343.0(214.0,466.0)$ & $359.0(253.0,490.0)$ \\
\hline Small LDL-P (nmol/L), median (Q1, Q3) & $614.0(463.0,765.0)$ & $613.0(463.0,775.0)$ \\
\hline HDL-P total $(\mu \mathrm{mol} / \mathrm{L})$, mean $\pm \mathrm{SD}$ & $35.5 \pm 6.4$ & $34.6 \pm 6.0$ \\
\hline Large HDL-P ( $\mu \mathrm{mol} / \mathrm{L})$, median (Q1, Q3) & $5.0(3.3,7.6)$ & $4.6(2.9,7.3)$ \\
\hline Medium HDL-P ( $\mu \mathrm{mol} / \mathrm{L})$, median (Q1, Q3) & $9.4(6.1,13.0)$ & $9.3(6.3,12.9)$ \\
\hline Small HDL-P ( $\mu \mathrm{mol} / \mathrm{L})$, median (Q1, Q3) & $20.1(16.4,23.1)$ & $19.3(16.0,22.6)$ \\
\hline VLDL-P/Chylomicron total (nmol/L), median (Q1, Q3) & $50.4(34.1,71.5)$ & $43.9(28.5,69.7)$ \\
\hline Large VLDL-P/Chylomicron (nmol/L), median (Q1, Q3) & $3.3(1.6,6.7)$ & $2.9(1.2,5.7)$ \\
\hline Medium VLDL-P (nmol/L), median (Q1, Q3) & $17.5(10.0,31.0)$ & $16.2(9.3,27.6)$ \\
\hline Small VLDL-P (nmol/L), median (Q1, Q3) & $26.1(17.7,38.3)$ & $23.2(15.3,35.2)$ \\
\hline IDL-P (nmol/L), median (Q1, Q3) & $76.0(40.0,124.0)$ & $72.0(40.0,115.0)$ \\
\hline
\end{tabular}


HDL-C, high-density lipoprotein cholesterol; IDL-P, intermediate-density lipoprotein particle concentration; LDL-C, low-density lipoprotein cholesterol; Q1, Q3, first and third quartiles; SD, standard deviation; VLDL-C, very low-density lipoprotein cholesterol; VLDL-P, very low-density lipoprotein particle concentration

*Defined as having been previously diagnosed with diabetes, baseline use of glucose-lowering medication, baseline fasting plasma glucose $\geq 126 \mathrm{mg} / \mathrm{dL}$, or baseline $\mathrm{HbA} 1 \mathrm{c} \geq 6.5 \%$ 
Table 2. Percent Change in Lipids and Apolipoproteins from Baseline to Week 52

\begin{tabular}{lccccc}
\hline & \multicolumn{2}{c}{ Placebo } & & \multicolumn{2}{c}{ Evolocumab 420 mg QM } \\
\cline { 2 - 3 } \cline { 5 - 6 } Variable & $\mathbf{n}$ & $\begin{array}{c}\text { Mean } \pm \text { SE or } \\
\text { Median (Q1, Q3) }\end{array}$ & & $\mathbf{n}$ & $\begin{array}{c}\text { Mean } \pm \text { SE or } \\
\text { Median (Q1, Q3) }\end{array}$ \\
\hline LDL-C & 250 & $7.0 \pm 1.8$ & & 309 & $-53.0 \pm 1.7$ \\
HDL-C & 255 & $0.3 \pm 0.9$ & & 313 & $5.7 \pm 0.9$ \\
VLDL-C & 253 & $9.1(-19.1,48.5)$ & & 311 & $-13.0(-37.5,20.0)$ \\
ApoB & 267 & $2.2 \pm 1.4$ & & 325 & $-42.6 \pm 1.2$ \\
ApoA1 & 267 & $-1.2 \pm 0.7$ & & 325 & $2.5 \pm 0.6$ \\
ApoB/ApoA1 & 267 & $4.1 \pm 1.5$ & & 325 & $-43.2 \pm 1.4$ \\
Triglycerides & 255 & $3.5(-16.7,24.8)$ & & 313 & $-9.5(-26.5,12.4)$ \\
Total cholesterol & 255 & $4.7 \pm 1.2$ & & 313 & $-29.3 \pm 1.0$ \\
\hline
\end{tabular}

ApoA1, apolipoprotein A1; ApoB, apolipoprotein B; HDL-C, high-density lipoprotein cholesterol; LDL-C, low-density lipoprotein cholesterol; Q1, Q3, first and third quartiles; SE, standard error; VLDL-C, very low-density lipoprotein cholesterol 
Table 3. Lipoprotein and Remnant Particle Concentrations and Percent Change from Baseline to Week 52

\begin{tabular}{|c|c|c|c|c|}
\hline \multirow[b]{2}{*}{ Variable } & \multicolumn{2}{|r|}{ Placebo } & \multicolumn{2}{|c|}{ Evolocumab 420 mg QM } \\
\hline & $\mathbf{n}$ & & $\mathbf{n}$ & \\
\hline LDL-P total & & & & \\
\hline Mean $\pm \mathrm{SD},(\mathrm{nmol} / \mathrm{L})$ & 246 & $1110.3 \pm 326.2$ & 300 & $609.8 \pm 336.9$ \\
\hline Percent change from baseline, mean $[95 \% \mathrm{Cl}]$ & 236 & $6.4[2.9,9.9]$ & 294 & $-44.1^{\mathrm{a}}[-47.2,-40.9]$ \\
\hline HDL-P total & & & & \\
\hline Mean $\pm \mathrm{SD},(\mu \mathrm{mol} / \mathrm{L})$ & 246 & $35.4 \pm 6.1$ & 300 & $37.5 \pm 6.2$ \\
\hline Percent change from baseline, mean $[95 \% \mathrm{Cl}]$ & 236 & $-0.1[-1.6,1.4]$ & 294 & $9.4^{\mathrm{a}}[7.5,11.4]$ \\
\hline Large LDL-P & & & & \\
\hline Median (Q1, Q3), (nmol/L) & 246 & $362.5(231.0,532.0)$ & 300 & $91.5(33.0,180.5)$ \\
\hline Percent change from baseline, median (Q1, Q3) & 233 & $5.1(-22.8,43.4)$ & 292 & $-73.7^{\mathrm{a}}(-89.8,-50.9)$ \\
\hline $\begin{array}{l}\text { Small LDL-P } \\
\text { Median (Q1, Q3), (nmol/L) }\end{array}$ & 246 & $615.0(460.0,775.0)$ & 300 & $367.0(274.0,507.5)$ \\
\hline Percent change from baseline, median (Q1, Q3) & 236 & $3.8(-16.9,29.0)$ & 294 & $-35.4^{\mathrm{a}}(-56.7,-11.4)$ \\
\hline $\begin{array}{l}\text { VLDL-P and Chylomicron total } \\
\text { Median (Q1, Q3), (nmol/L) }\end{array}$ & 246 & $49.4(32.3,75.4)$ & 300 & $35.8(25.1,53.7)$ \\
\hline Percent change from baseline, median (Q1, Q3) & 236 & $-0.3(-26.3,31.7)$ & 294 & $-15.3^{\mathrm{b}}(-39.3,15.4)$ \\
\hline $\begin{array}{l}\text { Large VLDL-P and Chylomicron } \\
\text { Median (Q1, Q3), (nmol/L) }\end{array}$ & 246 & $3.1(1.4,6.0)$ & 300 & $3.1(1.6,6.4)$ \\
\hline Percent change from baseline, median (Q1, Q3) & 236 & $1.0(-41.8,60.4)$ & 294 & $10.5(-26.1,100.0)$ \\
\hline $\begin{array}{l}\text { Medium VLDL-P } \\
\text { Median (Q1, Q3), (nmol/L) }\end{array}$ & 246 & $18.2(10.3,31.0)$ & 300 & $15.1(8.2,25.3)$ \\
\hline Percent change from baseline, median (Q1, Q3) & 235 & $7.1(-36.3,50.8)$ & 292 & $-15.2(-47.7,48.3)$ \\
\hline
\end{tabular}


Median (Q1, Q3), (nmol/L)

Percent change from baseline, median (Q1, Q3)

\section{IDL-P}

Median (Q1, Q3), (nmol/L)

Percent change from baseline, median (Q1, Q3)

$\begin{array}{cccc}246 & 26.2(16.2,37.0) & 300 & 16.8(10.8,25.1) \\ 236 & -7.5(-33.1,30.4) & 293 & -29.0^{\mathrm{a}}(-54.1,18.3) \\ 246 & 74.0(44.0,125.0) & 300 & 45.5(26.0,79.0) \\ 236 & 0(-47.4,87.5) & 294 & -36.2^{\mathrm{a}}(-69.8,22.0)\end{array}$

HDL-C, high-density lipoprotein cholesterol; IDL-P, intermediate-density lipoprotein particle concentration; LDL, low-density lipoprotein; LDL-P, LDL particle concentration; Q1, Q3, first and third quartiles; QM, once every month; SD, standard deviation; VLDL-P, very low-density lipoprotein particle concentration

$P$ values reported are for treatment differences (evolocumab versus placebo) tested using two-sample t-test for LDL-P and HDL-P. All other parameters were analyzed using the Wilcoxon rank sum test.

${ }^{\mathrm{a}} P<.0001 ;{ }^{\mathrm{b}} P<.001 ;{ }^{\mathrm{c}} P<.01$ 
Table 4. Percent Change in LDL-P and LDL-C from Baseline to Week 52 by Concordant/Discordant Status

\begin{tabular}{|c|c|c|c|c|c|c|}
\hline & \multicolumn{2}{|c|}{$\begin{array}{l}\text { Concordant } \\
(n=272)\end{array}$} & \multicolumn{2}{|c|}{$\begin{array}{c}\text { Discordant } \\
\text { LDL-P < LDL-C } \\
(\mathrm{n}=128)\end{array}$} & \multicolumn{2}{|c|}{$\begin{array}{c}\text { Discordant } \\
\text { LDL-P > LDL-C } \\
(n=130)\end{array}$} \\
\hline & $\begin{array}{l}\text { Placebo } \\
(n=123)\end{array}$ & $\begin{array}{l}\text { Evolocumab } \\
\qquad(n=149)\end{array}$ & $\begin{array}{l}\text { Placebo } \\
(n=58)\end{array}$ & $\begin{array}{c}\text { Evolocumab } \\
\qquad(n=70)\end{array}$ & $\begin{array}{l}\text { Placebo } \\
(n=55)\end{array}$ & $\begin{array}{l}\text { Evolocumab } \\
\qquad(n=75)\end{array}$ \\
\hline LDL-P, mean \pm SE & $6.2 \pm 2.7$ & $-47.4 \pm 1.9^{\star}$ & $9.4 \pm 3.2$ & $-37.5 \pm 3.8^{*}$ & $3.6 \pm 3.4$ & $-43.6 \pm 3.4^{*}$ \\
\hline $\mathrm{LDL}-\mathrm{C}$, mean $\pm \mathrm{SE}$ & $7.6 \pm 2.9$ & $-55.4 \pm 2.0^{*}$ & $3.5 \pm 2.6$ & $-50.7 \pm 3.9^{*}$ & $13.7 \pm 3.7$ & $-48.5 \pm 4.4^{*}$ \\
\hline
\end{tabular}


Table 5. Percent Change in Particle Sizes from Baseline to Week 52

\begin{tabular}{|c|c|c|c|c|}
\hline \multirow[b]{2}{*}{ Variable } & \multicolumn{2}{|r|}{ Placebo } & \multicolumn{2}{|c|}{ Evolocumab $420 \mathrm{mg}$ QM } \\
\hline & $\mathbf{n}$ & Mean $(95 \% \mathrm{Cl})$ & $\mathbf{n}$ & Mean $(95 \% \mathrm{Cl})$ \\
\hline \multicolumn{5}{|l|}{$\overline{\mathrm{LDL}}$} \\
\hline All & 234 & $0(-0.3,0.2)$ & 244 & $-1.7(-2.0,-1.4)^{\mathrm{a}}$ \\
\hline Type 2 diabetes* & 33 & $-0.2(-1.0,0.6)$ & 46 & $-0.8(-1.6,-0.1)$ \\
\hline Impaired fasting glucose ${ }^{\dagger}$ & 83 & $-0.2(-0.6,0.2)$ & 85 & $-2.0(-2.6,-1.5)^{\mathrm{a}}$ \\
\hline Metabolic syndrome ${ }^{\ddagger}$ & 83 & $-0.1(-0.5,0.3)$ & 81 & $-1.6(-2.1,-1.1)^{\mathrm{a}}$ \\
\hline \multicolumn{5}{|l|}{ HDL } \\
\hline All & 236 & $-0.02(-0.4,0.4)$ & 294 & $1.1(0.7,1.5)^{b}$ \\
\hline Type 2 diabetes ${ }^{*}$ & 33 & $-0.3(-1.8,1.1)$ & 57 & $1.1(0.3,1.9)$ \\
\hline Impaired fasting glucose ${ }^{\dagger}$ & 84 & $0.1(-0.6,0.8)$ & 103 & $1.1(0.5,1.7)$ \\
\hline Metabolic syndrome $e^{\ddagger}$ & 84 & $0.3(-0.3,1.0)$ & 94 & $1.4(0.5,2.2)$ \\
\hline \multicolumn{5}{|l|}{ VLDL } \\
\hline All & 234 & $0.9(-0.8,2.5)$ & 287 & $8.7(7.0,10.5)^{\mathrm{a}}$ \\
\hline Type 2 diabetes* & 31 & $4.0(-0.9,8.8)$ & 55 & $9.2(5.0,13.5)$ \\
\hline Impaired fasting glucose ${ }^{\dagger}$ & 84 & $1.2(-1.6,4.0)$ & 102 & $8.2(5.6,10.9)^{b}$ \\
\hline Metabolic syndrome ${ }^{\ddagger}$ & 84 & $1.3(-1.3,3.9)$ & 93 & $6.8(4.4,9.3)^{c}$ \\
\hline
\end{tabular}

$\mathrm{Cl}$, confidence interval; HDL, high-density lipoprotein; LDL, low-density lipoprotein; VLDL, very low-density lipoprotein

${ }^{\mathrm{a}} P<.0001 ;{ }^{\mathrm{b}} P<.001 ;{ }^{\mathrm{c}} P<.01$

'Defined as having been previously diagnosed with diabetes, baseline use of glucose-lowering medication, baseline FPG $\geq 126 \mathrm{mg} / \mathrm{dL}$, or baseline $\mathrm{HbA} 1 \mathrm{c} \geq 6.5 \%$

${ }^{\dagger}$ Defined as the absence of type 2 diabetes with a fasting plasma glucose $\geq 100 \mathrm{mg} / \mathrm{dL}$ and < $126 \mathrm{mg} / \mathrm{dL}$ at baseline

${ }^{\ddagger}$ Defined using modified AHA/NHLBI criteria as the absence of type 2 diabetes and the presence of 3 or more of the following components: elevated waist circumference (non-Asian men $\geq 102 \mathrm{~cm}$, non-Asian women $\geq 88 \mathrm{~cm}$, Asian men $\geq 90 \mathrm{~cm}$, Asian women $\geq 80 \mathrm{~cm}$ ); triglycerides $\geq 1.7 \mathrm{mmol} / \mathrm{L}(150 \mathrm{mg} / \mathrm{dL})$; low HDL cholesterol (men $<40 \mathrm{mg} / \mathrm{dL}$, women $<50$ $\mathrm{mg} / \mathrm{dL}$ ); high blood pressure (systolic $\geq 130 \mathrm{mmHg}$, diastolic $\geq 85 \mathrm{mmHg}$, medical history of hypertension); and fasting plasma glucose $\geq 100 \mathrm{mg} / \mathrm{dL}$ 


\begin{tabular}{|c|c|c|c|c|}
\hline & \multicolumn{2}{|c|}{ Placebo } & \multicolumn{2}{|c|}{$\begin{array}{c}\text { Evolocumab } 420 \mathrm{mg} \\
\mathrm{QM}\end{array}$} \\
\hline & $\mathbf{n}$ & & $\mathbf{n}$ & \\
\hline \multicolumn{5}{|l|}{ LDL-P total } \\
\hline \multicolumn{5}{|l|}{ Mean (SD), nmol/L } \\
\hline All patients & 246 & 1110.3 (326.2) & 300 & $609.8(336.9)$ \\
\hline Type 2 diabetes* & 35 & $1095.6(332.6)$ & 58 & $653.4(379.7)$ \\
\hline Impaired fasting glucose ${ }^{\dagger}$ & 88 & $1098.1(329.2)$ & 104 & $585.5(317.4)$ \\
\hline Metabolic syndrome ${ }^{\ddagger}$ & 89 & $1156.8(341.7)$ & 95 & $662.2(336.6)$ \\
\hline \multicolumn{5}{|l|}{$\begin{array}{l}\text { Percent change from } \\
\text { baseline, mean }[95 \% \mathrm{Cl}]\end{array}$} \\
\hline All patients & 236 & $6.4[2.9,9.9]$ & 294 & $\begin{array}{c}-44.1^{\mathrm{a}}[-47.2,- \\
40.9]\end{array}$ \\
\hline Type 2 diabetes* & 33 & $5.7[-2.5,13.8]$ & 57 & $\begin{array}{c}-42.4^{\mathrm{a}}[-49.8,- \\
35.0]\end{array}$ \\
\hline Impaired fasting glucose ${ }^{\dagger}$ & 84 & $4.9[-0.9,10.6]$ & 103 & $\begin{array}{c}-46.3^{\mathrm{a}}[-51.2,- \\
41.3]\end{array}$ \\
\hline Metabolic syndrome ${ }^{\ddagger}$ & 84 & $3.6[-1.7,9.0]$ & 94 & $\begin{array}{c}-43.6^{\mathrm{a}}[-48.7,- \\
38.6]\end{array}$ \\
\hline \multicolumn{5}{|l|}{ HDL-P total } \\
\hline All patients & 246 & $35.4(6.1)$ & 300 & $37.5(6.2)$ \\
\hline Type 2 diabetes* & 35 & $32.4(6.1)$ & 58 & $36.4(6.9)$ \\
\hline Impaired fasting glucose ${ }^{\dagger}$ & 88 & $35.6(6.2)$ & 104 & $38.5(5.8)$ \\
\hline Metabolic syndrome ${ }^{\ddagger}$ & 89 & $34.6(6.9)$ & 95 & $36.6(6.6)$ \\
\hline \multicolumn{5}{|l|}{$\begin{array}{l}\text { Percent change from } \\
\text { baseline, mean }[95 \% \mathrm{Cl}]\end{array}$} \\
\hline All Patients & 236 & $-0.1[-1.6,1.4]$ & 294 & $9.4^{a}[7.5,11.4]$ \\
\hline Type 2 diabetes ${ }^{*}$ & 33 & $-1.1[-5.0,2.8]$ & 57 & $7.3^{\mathrm{C}}[4.0,10.7]$ \\
\hline Impaired fasting glucose ${ }^{\dagger}$ & 84 & $0.7[-2.3,3.7]$ & 103 & $10.5^{\mathrm{b}}[6.4,14.5]$ \\
\hline Metabolic syndrome ${ }^{\ddagger}$ & 84 & $0.0[-2.9,2.9]$ & 94 & $10.1^{\mathrm{b}}[5.5,14.8]$ \\
\hline \multicolumn{5}{|l|}{ Large LDL-P } \\
\hline All patients & 246 & $\begin{array}{c}362.5(231.0 \\
532.0)\end{array}$ & 300 & $91.5(33.0,180.5)$ \\
\hline Type 2 diabetes ${ }^{*}$ & 35 & $\begin{array}{c}313.0(191.0 \\
451.0)\end{array}$ & 58 & $88.0(38.0,197.0)$ \\
\hline Impaired fasting glucose ${ }^{\dagger}$ & 88 & $\begin{array}{c}322.0(194.0 \\
481.0)\end{array}$ & 104 & $83.0(24.5,153.5)$ \\
\hline Metabolic syndrome ${ }^{\ddagger}$ & 89 & $\begin{array}{l}273.0(159.0 \\
414.0)\end{array}$ & 95 & $97.0(31.0,169.0)$ \\
\hline
\end{tabular}

Percent change from baseline, median (Q1, Q3) 


\begin{tabular}{|c|c|c|c|c|}
\hline All patients & 233 & $5.1(-22.8,43.4)$ & 292 & $\begin{array}{c}-73.7^{\mathrm{a}}(-89.8,- \\
50.9)\end{array}$ \\
\hline Type 2 diabetes* & 33 & $-3.1(-28.0,45.7)$ & 56 & $\begin{array}{c}-65.8^{\mathrm{a}}(-85.9,- \\
47.5)\end{array}$ \\
\hline Impaired fasting glucose ${ }^{\dagger}$ & 83 & $3.0(-23.3,38.6)$ & 103 & $\begin{array}{c}-77.8^{\mathrm{a}}(-92.1,- \\
48.8)\end{array}$ \\
\hline Metabolic syndrome ${ }^{\ddagger}$ & 81 & $3.0(-30.5,45.3)$ & 93 & $\begin{array}{c}-67.3^{\mathrm{a}}(-88.7,- \\
45.6)\end{array}$ \\
\hline \multicolumn{5}{|l|}{$\begin{array}{l}\text { mall LDL-P } \\
\text { ledian (Q1, Q3), nmol/L }\end{array}$} \\
\hline All patients & 246 & $\begin{array}{c}615.0(460.0 \\
775.0)\end{array}$ & 300 & $\begin{array}{c}367.0(274.0 \\
507.5)\end{array}$ \\
\hline Type 2 diabetes* & 35 & $\begin{array}{c}660.0(522.0 \\
836.0)\end{array}$ & 58 & $\begin{array}{c}437.0(312.0 \\
496.0)\end{array}$ \\
\hline Impaired fasting glucose ${ }^{\dagger}$ & 88 & $\begin{array}{c}622.5(473.0 \\
786.5)\end{array}$ & 104 & $\begin{array}{c}360.5(283.0 \\
502.0)\end{array}$ \\
\hline Metabolic syndrome ${ }^{\ddagger}$ & 89 & $\begin{array}{l}695.0(589.0 \\
892.0)\end{array}$ & 95 & $\begin{array}{c}454.0(300.0 \\
610.0)\end{array}$ \\
\hline
\end{tabular}

Percent change from baseline, median (Q1, Q3)

All patients

236

$3.8(-16.9,29.0)$

294

$-35.4^{\mathrm{a}}(-56.7,-$ 11.4)

Type 2 diabetes*

33

$6.0(-8.1,50.7)$ $-35.5^{\mathrm{a}}(-56.8,-$

Impaired fasting glucose ${ }^{\dagger}$

84

$5.6(-15.5,29.0)$

Metabolic syndrome

$4.0(-11.5,27.5)$

57

84

$103-35.2^{\mathrm{a}}(-56.7,-2.1)$

94

$-32.6^{\mathrm{a}}(-54.4,-$ 12.6)

VLDL-P and Chylomicron total Median (Q1, Q3), nmol/L

All patients

Type 2 diabetes*

$49.4(32.3,75.4)$

$43.8(31.3,58.1)$

300

$35.8(25.1,53.7)$

Impaired fasting glucose ${ }^{\dagger}$

88

$51.3(32.7,77.9)$

58

$35.2(27.0,48.3)$

Metabolic syndrome ${ }^{\ddagger}$

89

$67.7(46.8,86.0)$

104

$35.1(25.0,50.1)$

$95 \quad 42.1(26.3,61.4)$

Percent change from baseline, median (Q1, Q3)

All patients

236

Type 2 diabetes*

33

$-0.3(-26.3,31.7)$

$294-15.3^{\mathrm{b}}(-39.3,15.4)$

Impaired fasting glucose ${ }^{\dagger}$

$-10.3(-29.0,14.6)$

$57-17.3(-39.3,19.0)$

$84 \quad-4.4(-30.9,29.9)$

$103-12.9(-41.3,14.2)$

Metabolic syndrome ${ }^{\ddagger}$

$-4.3(-25.4,16.2)$

$94-24.5^{\mathrm{b}}(-43.7,-3.0)$

Large VLDL-P and Chylomicron Median (Q1, Q3), nmol/L

All patients

246

Type 2 diabetes*

$3.1(1.4,6.0)$

300

$3.1(1.6,6.4)$

35

$3.1(1.5,4.6)$

58

$4.0(2.1,7.4)$

Impaired fasting glucose ${ }^{\dagger}$

$4.0(1.8,7.1)$

104

$3.0(1.7,5.9)$

Metabolic syndrome ${ }^{\ddagger}$

$5.6(3.0,9.6)$

95

$4.6(2.2,8.3)$

Percent change from baseline, median (Q1, Q3) 


\begin{tabular}{|c|c|c|c|c|}
\hline All patients & 236 & $1.0(-41.8,60.4)$ & 294 & $10.5(-26.1,100.0)$ \\
\hline Type 2 diabetes* & 33 & $26.7(-23.8,66.7)$ & 57 & $10.9(-33.3,62.3)$ \\
\hline Impaired fasting glucose ${ }^{\dagger}$ & 84 & $2.8(-43.6,60.4)$ & 103 & $0.0(-25.0,82.9)$ \\
\hline Metabolic syndrome ${ }^{\ddagger}$ & 84 & $-1.9(-42.8,60.4)$ & 94 & $-3.3(-31.3,45.5)$ \\
\hline \multicolumn{5}{|l|}{ Medium VLDL-P } \\
\hline All patients & 246 & $18.2(10.3,31.0)$ & 300 & $15.1(8.2,25.3)$ \\
\hline Type 2 diabetes* & 35 & $16.6(9.7,22.7)$ & 58 & $15.8(8.2,21.4)$ \\
\hline Impaired fasting glucose ${ }^{\dagger}$ & 88 & $19.1(9.4,31.1)$ & 104 & $13.9(8.5,24.7)$ \\
\hline Metabolic syndrome $\ddagger$ & 89 & $25.4(17.2,37.0)$ & 95 & $18.8(9.0,28.1)$ \\
\hline \multicolumn{5}{|l|}{$\begin{array}{l}\text { Percent change from } \\
\text { baseline, median (Q1, Q3) }\end{array}$} \\
\hline All patients & 235 & $7.1(-36.3,50.8)$ & 292 & $-15.2(-47.7,48.3)$ \\
\hline Type 2 diabetes* & 33 & $-10.2(-49.9,32.0)$ & 57 & $-17.4(-45.1,38.5)$ \\
\hline Impaired fasting glucose ${ }^{\dagger}$ & 84 & $3.8(-40.0,40.4)$ & 103 & $-14.1(-48.4,71.6)$ \\
\hline Metabolic syndrome ${ }^{\ddagger}$ & 84 & $-1.3(-39.9,32.8)$ & 93 & $-21.3(-47.9,19.7)$ \\
\hline \multicolumn{5}{|l|}{ Small VLDL-P } \\
\hline \multicolumn{5}{|l|}{ Median (Q1, Q3), nmol/L } \\
\hline All patients & 246 & $26.2(16.2,37.0)$ & 300 & $16.8(10.8,25.1)$ \\
\hline Type 2 diabetes* & 35 & $24.4(14.6,32.7)$ & 58 & $18.5(9.6,25.0)$ \\
\hline Impaired fasting glucose ${ }^{\dagger}$ & 88 & $27.9(15.7,39.0)$ & 104 & $16.2(12.1,23.7)$ \\
\hline Metabolic syndrome ${ }^{\ddagger}$ & 89 & $31.6(19.0,42.8)$ & 95 & $17.0(11.2,27.1)$ \\
\hline \multicolumn{5}{|l|}{$\begin{array}{l}\text { Percent change from } \\
\text { baseline, median (Q1, Q3) }\end{array}$} \\
\hline All patients & 236 & $-7.5(-33.1,30.4)$ & 293 & $-29.0^{\mathrm{a}}(-54.1,18.3)$ \\
\hline Type 2 diabetes ${ }^{*}$ & 33 & $-3.9(-26.9,64.0)$ & 57 & $-22.9(-51.2,18.8)$ \\
\hline Impaired fasting glucose ${ }^{\dagger}$ & 84 & $-11.4(-37.5,20.9)$ & 103 & $-28.9(-53.6,13.0)$ \\
\hline Metabolic syndrome ${ }^{\ddagger}$ & 84 & $-7.4(-34.1,19.5)$ & 94 & $-34.6^{c}(-52.7,10.0)$ \\
\hline \multicolumn{5}{|l|}{$\begin{array}{l}\text { IDL-P } \\
\text { Median (Q1, Q3), nmol/L }\end{array}$} \\
\hline All patients & 246 & $74.0(44.0,125.0)$ & 300 & $45.5(26.0,79.0)$ \\
\hline Type 2 diabetes* & 35 & $68.0(27.0,85.0)$ & 58 & $41.5(29.0,78.0)$ \\
\hline Impaired fasting glucose ${ }^{\dagger}$ & 88 & $75.0(43.0,129.0)$ & 104 & $43.0(23.0,88.5)$ \\
\hline Metabolic syndrome $e^{\ddagger}$ & 89 & $79.0(42.0,134.0)$ & 95 & $39.0(20.0,79.0)$ \\
\hline \multicolumn{5}{|l|}{$\begin{array}{l}\text { Percent change from } \\
\text { baseline, median (Q1, Q3) }\end{array}$} \\
\hline All patients & 236 & $0(-47.4,87.5)$ & 294 & $-36.2^{\mathrm{a}}(-69.8,22.0)$ \\
\hline Type 2 diabetes ${ }^{*}$ & 33 & $0(-36.0,34.9)$ & 57 & $-33.8(-69.0,38.1)$ \\
\hline Impaired fasting glucose ${ }^{\dagger}$ & 84 & $-11.8(-53.9,93.8)$ & 103 & $-37.8^{\mathrm{c}}(-70.6,14.2)$ \\
\hline Metabolic syndrome ${ }^{\ddagger}$ & 84 & $-12.7(-59.6,72.1)$ & 94 & $-53.1^{\mathrm{b}}(-79.3,12.5)$ \\
\hline
\end{tabular}

HDL-C, high-density lipoprotein cholesterol; IDL-P, intermediate-density lipoprotein particle concentration; LDL, low-density lipoprotein; LDL-P, LDL particle concentration; Q1, Q3, first and third quartiles; QM, once every month; SD, standard deviation; VLDL-P, very low-density lipoprotein particle concentration 
$P$ values reported are for treatment differences (evolocumab versus placebo) within each subgroup, tested using two-sample t-test for LDL-P and HDL-P. All other parameters were analyzed using the Wilcoxon rank sum test

${ }^{\mathrm{a}} P<.0001 ;{ }^{\mathrm{b}} P<.001 ;{ }^{\mathrm{c}} P<.01$

"Defined as having been previously diagnosed with diabetes, baseline use of glucose-lowering medication, baseline FPG $\geq 126 \mathrm{mg} / \mathrm{dL}$, or baseline $\mathrm{HbA} 1 \mathrm{c} \geq 6.5 \%$

${ }^{\dagger}$ Defined as the absence of type 2 diabetes with a fasting plasma glucose $\geq 100 \mathrm{mg} / \mathrm{dL}$ and < $126 \mathrm{mg} / \mathrm{dL}$ at baseline

${ }^{\ddagger}$ Defined using modified AHA/NHLBI criteria as the absence of type 2 diabetes and the presence of 3 or more of the following components: elevated waist circumference (non-Asian men $\geq 102 \mathrm{~cm}$, non-Asian women $\geq 88 \mathrm{~cm}$, Asian men $\geq 90 \mathrm{~cm}$, Asian women $\geq 80 \mathrm{~cm}$ ); triglycerides $\geq 1.7 \mathrm{mmol} / \mathrm{L}(150 \mathrm{mg} / \mathrm{dL}$ ); low HDL cholesterol (men $<40 \mathrm{mg} / \mathrm{dL}$, women $<50$ $\mathrm{mg} / \mathrm{dL}$ ); high blood pressure (systolic $\geq 130 \mathrm{mmHg}$, diastolic $\geq 85 \mathrm{mmHg}$, medical history of hypertension); and fasting plasma glucose $\geq 100 \mathrm{mg} / \mathrm{dL}$ 
Supplemental Table 2. Percent Change in LDL-P and LDL-C Levels from Baseline to Week 52 by Concordance/Discordance Status Using Two LDL-C Estimation Methods

\begin{tabular}{|c|c|c|c|c|c|c|c|c|c|c|c|c|}
\hline & \multicolumn{6}{|c|}{ Friedewald equation estimate } & \multicolumn{6}{|c|}{ Triglycerides:VLDL-C ratio $^{1}$} \\
\hline & \multicolumn{2}{|c|}{$\begin{array}{c}\text { Concordant } \\
n=272\end{array}$} & \multicolumn{2}{|c|}{$\begin{array}{c}\text { Discordant } \\
\text { LDL-P < LDL- } \\
\mathrm{C} \\
\mathrm{n}=128\end{array}$} & \multicolumn{2}{|c|}{$\begin{array}{c}\text { Discordant } \\
\text { LDL-P > LDL- } \\
\text { C } \\
n=130 \\
\end{array}$} & \multicolumn{2}{|c|}{$\begin{array}{c}\text { Concordant } \\
n=280\end{array}$} & \multicolumn{2}{|c|}{$\begin{array}{c}\text { Discordant } \\
\text { LDL-P < LDL- } \\
\text { C } \\
n=125\end{array}$} & \multicolumn{2}{|c|}{$\begin{array}{c}\text { Discordant } \\
\text { LDL-P > LDL- } \\
\text { C } \\
n=125\end{array}$} \\
\hline & Pbo & Evo & Pbo & Evo & $\mathrm{Pbo}$ & Evo & Pbo & Evo & $\mathrm{Pbo}$ & Evo & $\mathrm{Pbo}$ & Evo \\
\hline \multirow{3}{*}{$\begin{array}{l}\text { LDL-P, } \\
\text { Mean } \\
\text { (SE) } \\
\text { LDL-C, } \\
\text { Mean } \\
\text { (SE) }\end{array}$} & $\begin{array}{l}\mathrm{n}= \\
123\end{array}$ & $\begin{array}{l}\mathrm{n}= \\
149\end{array}$ & $\begin{array}{l}n= \\
58\end{array}$ & $\mathrm{n}=70$ & $\mathrm{n}=55$ & $\mathrm{n}=75$ & $\begin{array}{l}\mathrm{n}= \\
127\end{array}$ & $\begin{array}{l}\mathrm{n}= \\
153\end{array}$ & $\begin{array}{c}\mathrm{n}= \\
57\end{array}$ & $\mathrm{n}=68$ & $n=52$ & $n=73$ \\
\hline & $\begin{array}{c}6.2 \\
(2.7)\end{array}$ & $\begin{array}{c}-47.4 \\
(1.9)\end{array}$ & $\begin{array}{c}9.4 \\
(3.2)\end{array}$ & $\begin{array}{c}-37.5 \\
(3.8)\end{array}$ & $\begin{array}{l}3.6 \\
(3.4)\end{array}$ & $\begin{array}{c}-43.6 \\
(3.4)\end{array}$ & $\begin{array}{l}7.1 \\
(2.6)\end{array}$ & $\begin{array}{c}-45.4 \\
(2.0)\end{array}$ & $\begin{array}{l}7.8 \\
(3.2)\end{array}$ & $\begin{array}{c}-39.1 \\
(3.7)\end{array}$ & $\begin{array}{l}3.2 \\
(3.6)\end{array}$ & $\begin{array}{c}-46.0 \\
(3.5)\end{array}$ \\
\hline & $\begin{array}{l}7.6 \\
(2.9)\end{array}$ & $\begin{array}{c}-55.4 \\
(2.0)\end{array}$ & $\begin{array}{l}3.5 \\
(2.6)\end{array}$ & $\begin{array}{l}-50.7 \\
(3.9)\end{array}$ & $\begin{array}{l}13.7 \\
(3.7)\end{array}$ & $\begin{array}{c}-48.5 \\
(4.4)\end{array}$ & $\begin{array}{l}8.3 \\
(2.7)\end{array}$ & $\begin{array}{l}-51.5 \\
(2.3)\end{array}$ & $\begin{array}{c}1.3 \\
(2.7)\end{array}$ & $\begin{array}{l}-51.5 \\
(3.1)\end{array}$ & $\begin{array}{l}15.2 \\
(3.8)\end{array}$ & $\begin{array}{c}-47.8 \\
(4.5)\end{array}$ \\
\hline \multicolumn{13}{|c|}{$\begin{array}{l}\text { Cl, confidence interval; Evo, evolocumab; LDL-C, low-density lipoprotein cholesterol; P, particle concentration; Pbo, placebo; SE, } \\
\text { standard error } \\
{ }^{1} \text { Martin SS, Blaha MJ, Elshazly MB, Toth PP, Kwiterovich PO, Blumenthal RS, Jones SR. Comparison of a novel method vs the } \\
\text { Friedewald equation for estimating low-density lipoprotein cholesterol levels from the standard lipid profile. JAMA 2013;310:2061-8. } \\
P \text { values are for the evolocumab versus placebo comparison } \\
{ }^{*} P<.0001\end{array}$} \\
\hline
\end{tabular}




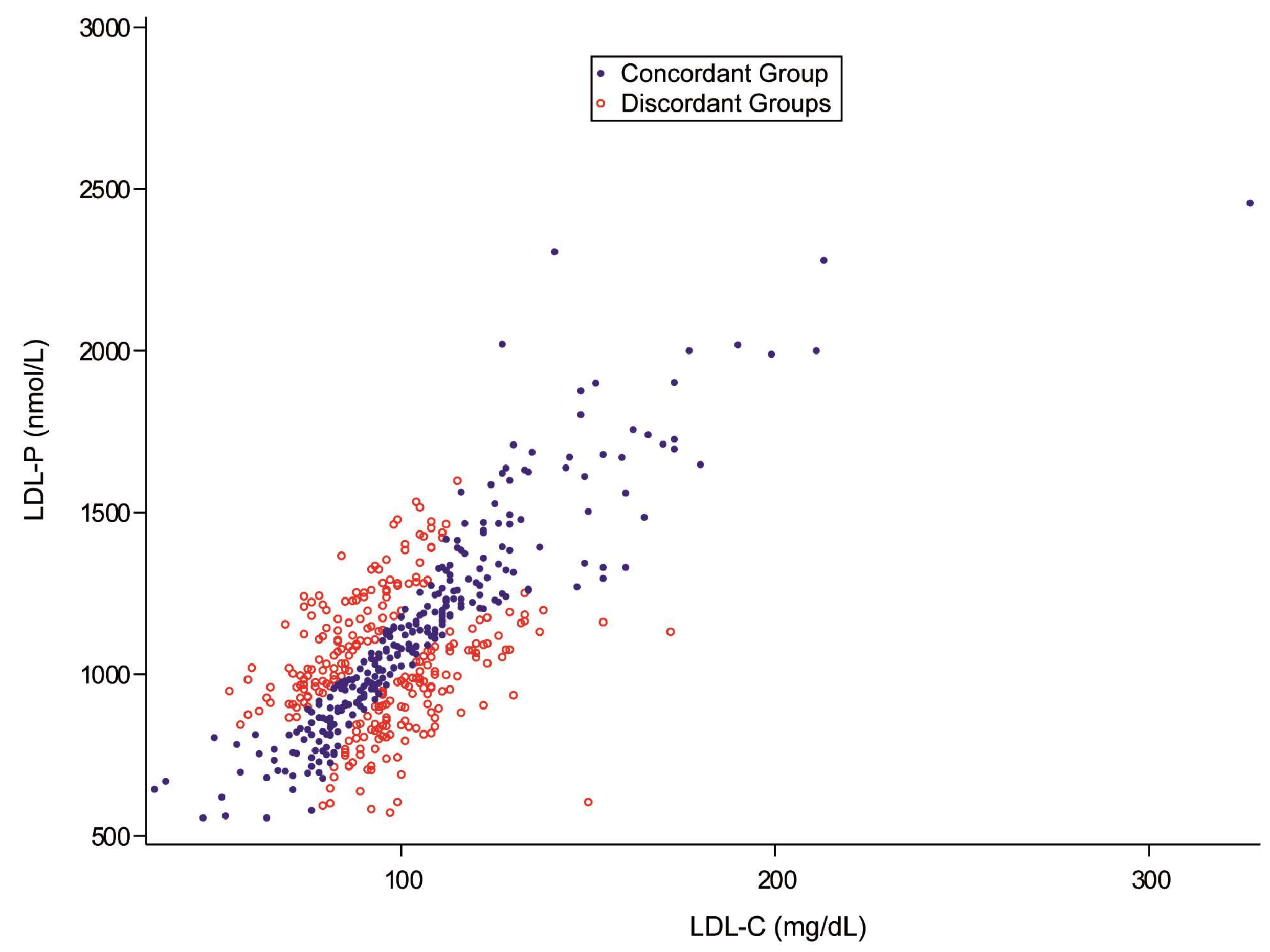

